\title{
Evaluation of traditional fire management in an Amazonian savanna
}

\author{
Rodrigo de Moraes Falleiro ${ }^{* 1}$, Maristella Aparecida Corrê $a^{* 2}$, Luciano Carregosa dos Santos ${ }^{* 3} e$ \\ Marcelo Siqueira de Oliveira*4
}

\begin{abstract}
*Brazilian Institute of Environment and Renewable Natural Resources (Ibama), Brasília, Brazil
* Contact email: 1 rodrigomfalleiro@gmail.com; 2 maristellaapc@gmail.com; 3 lucianocarregosa@gmail.com;

4 mso.sabia@gmail.com;
\end{abstract}

\begin{abstract}
Lavrado is a savanna located in the Amazon biome. Its full extent is strongly impacted by wildfires and prescribed burns, but there are few scientific studies on the effects of these fire regimes on this unique ecosystem. Recently, the traditional knowledge about the use of fire in the Lavrado has been retrieved from the indigenous communities that inhabit the region and applied as a strategy to protect against forest fires and to manage natural resources. This knowledge recommends the use of burns in open vegetation areas between September and December, in order to reduce forest fuel and induce the reproduction of edible fruit species. This present work aims to evaluate the effects of this traditional regime on the fruit species Byrsonima coccolobifolia (murici), Byrsonima crassifiolia (mirixi), Byrsonima verbascifolia (orelha de burro) and on creeping species of the Myrtacea family, popularly know as araçás. The treatments evaluated were modal burns (September and October), late burns (November and December), wildfires (January to March) and fire exclusion. The evaluated parameters were the proportion of individuals in reproduction, loss of reproductive structures due to fire and fruit yield per plant. The obtained results indicate different responses to the applied regimes. B. verbascifolia showed good reproductive rates in all treatments that include fire, while B. coccolobifolia and Myrtaceae (araçás) responded better to early prescribed burns. B. crassiflolia presented better reproductive rates in fire exclusion, followed by modal burns, late burns and, lastly, wildfires. In general, there is a tendency for modal burns to have higher reproduction rates, less loss of reproductive structures and higher fruit productivity than late burns for most species. However, this burning period is too short and unstable to allow management throughout the region. In addition, the effects on reproduction were more variable than those observed in the Brazilian Cerrado. As observed in the flooded regions of Araguaia and Xingu, the flood pulse and saturated soil appear to promote greater complexity of fire response, which needs to be further studied to determine the optimal management in this type of ecosystem.
\end{abstract}

Keywords: integrated fire management, prescribed burns, traditional knowledge, indigenous communities, lavrado roraimense, Amazon biome. 